\title{
Review
}

Journal of Innate
Immunity

\section{Natural Killer Cell Activation Secondary to Innate Pattern Sensing}

\author{
Tsukasa Seya Jun Kasamatsu Masahiro Azuma Hiroaki Shime \\ Misako Matsumoto \\ Department of Microbiology and Immunology, Hokkaido University Graduate School of Medicine, Sapporo, Japan
}

\section{Key Words}

Natural killer cell activation - Dendritic cell · Toll-like receptor $3 \cdot$ TICAM-1 $\cdot$ MyD88

\begin{abstract}
Recent progress in understanding the outcomes of patternrecognition by myeloid dendritic cells $(\mathrm{mDC})$ allows us to delineate the pathways driving natural killer (NK) cell activation. Mouse $\mathrm{mDC}$ mature in response to microbial patterns and are converted to an NK cell-activating phenotype. The MyD88 pathway, the Toll/IL-1 receptor homology domaincontaining adaptor molecule (TICAM)-1 (TRIF) pathway, and the interferon (IFN)- $\beta$ promoter stimulator 1 (IPS-1) pathway in $\mathrm{mDC}$ participate in driving NK activation, as shown by analyses in knockout mice. Studies using synthetic compounds for Toll-like receptors/RIG-I-like receptors have demonstrated that mDC-NK cell contact induces NK cell activation without the participation of cytokines in mice. In vivo bone marrow transplantation analysis revealed that the IPS1 pathway in nonmyeloid cells and the TICAM-1 pathway in $\mathrm{mDC}$ are crucial for dsRNA-mediated in vivo NK activation. These results infer the presence of cytokine-dependent and cytokine-independent modes of NK activation in conjunction with innate immune activation. Here, we focus on the IFN-inducing pathways and mDC-NK contact-induced NK activation and discuss the reported various NK activation modes.

Copyright $\odot 2011$ S. Karger AG, Basel
\end{abstract}

\section{Introduction}

Natural killer (NK) cells have the ability to kill certain tumor cells and infected cells [1]. A number of activating and inhibitory receptors have been implicated in NK cell recognition and elimination of target cells [2]. In addition, NK cell effector functions are induced or potentiated through recognition of microbial products by innate pattern recognition receptors (PRRs) that are expressed in various cell types, including myeloid cells and NK cells. In this way, dendritic cells may induce cytokines, such as interferon (IFN)- $\gamma$, and potentiate cytotoxicity by NK cells [3]. In mice, myeloid cells stimulate NK cells through cell-cell contact and with soluble mediators [4, 5]. Many factors including cytokines and molecules supporting direct contact by immune-related cells are reported to participate in NK activation [2-5]. Myeloid dendritic cells (mDC) and macrophages (Mf) often serve as a source of such activating factors as IL-12p70, IL-18, IL-15, and type I IFN.

It is well known that type I IFN activates NK cells. However, immature $\mathrm{mDC}$ only subfunctionally produce type I IFN and, consequently, IFN-dependent NK activation factors are maintained at basal levels through the IFN- $\alpha$ receptor (IFNAR) pathway in mice [6]. Infection or inflammation stimulates additional factors that render NK activation by $\mathrm{mDC}$ feasible $[4,5]$. Such factors that induce $\mathrm{mDC}$ maturation largely belong to a class of ex-

\section{KARGER}

Fax +4161306 1234

E-Mail karger@karger.ch

www.karger.com
(C) 2011 S. Karger AG, Basel

1662-811X/11/0033-0264\$38.00/0

Accessible online at:

www.karger.com/jin
Dr. Tsukasa Seya

Department of Microbiology and Immunology

Graduate School of Medicine, Hokkaido University

Kita-ku, Sapporo 060-8638 (Japan)

Tel. +81 11706 5073, E-Mail seya-tu@ @op.med.hokudai.ac.jp 
ogenous or endogenous pattern molecules designated pathogen-associated molecular patterns (PAMP)/damage-associated molecular patterns (DAMP) $[7,8]$. Research into signaling pathways in the innate immune system has indicated that PAMP and DAMP act on PRRs in $\mathrm{mDC} / \mathrm{Mf}$ and drive NK activation $[4,5,7,8]$. In addition, membrane molecules upregulated on the surface of $\mathrm{mDC}$ participate in $\mathrm{NK}$ activation in a process known as mDC-NK contact-mediated NK activation $[4,5]$. In this case, mature $\mathrm{mDC}$ and NK cells must be recruited to local lymph nodes, and their interactions lead to the emergence of effector NK cells in the periphery. However, it is unknown whether activation of NK cells is totally dependent on IFN or just shares the PRR pathways with IFN induction to upregulate other NK-activating molecules. Furthermore, it remains undetermined what microenvironment $\mathrm{mDC}$ require for maturation along with $\mathrm{NK}$ activation and what effectors $\mathrm{mDC}$ stimulate via the PRR pathways to participate in enhancing NK activity.

Recent progress in the innate pattern-sensing system suggests that $\mathrm{mDC}$ pattern recognition is a major event in driving $\mathrm{mDC}$ to an NK-activating phenotype [9-11]. These results add new insight into the currently accepted theory that the balance between a number of activating receptors and inhibitory receptors and their activation states are critical for NK activation [2, 3, 12, 13]. Insight into the mechanism behind NK cell activation may be gained via analysis of the molecular mechanisms by which PAMP/DAMP activate the immune system and, in particular, mDC. NK cells have the capacity to induce memory-like responses in a way comparable to T lymphocytes [14], and some subsets are specialized to produce the Th17 cytokine IL-22 [15] although their features are not always comparable to NK cells. These unique features of NK cells may be associated with $\mathrm{mDC}$ factors that drive NK activation, including the combination of stimuli required for PRR and the cytokines that act in conjunction with inhibitory/activating ligands on NK receptors [16]. This review collates recent advances in the innate molecules and pathways related to $\mathrm{mDC}$-mediated $\mathrm{NK}$ activation.

\section{Direct or Secondary Activation of NK Cells by Microbial Patterns}

DC/Mf as well as stromal cells express a variety of PRRs. In infection, these non-NK cell-derived mediators play a role in NK cell responses to pathogens [17]. Activation of these cells in response to PAMP can also lead to indirect NK activation which is mediated by affected accessory cells with altered membrane-associated molecules $[16,17]$. Both soluble factors and membrane molecules join NK cell activation. Several reviews mention the mode of direct and accessory cell-derived (secondary) NK activation $[2,8,16]$. We just summarized this issue to facilitate the introduction of $\mathrm{mDC} / \mathrm{Mf}$-mediated NK cell activation.

Pathogen molecules often interact with NK receptors. Examples of direct pathogen interaction with NK cells have been demonstrated in mouse cytomegalovirus, whose m157 molecule interacts with Ly49H, an NK cellactivating/inhibitory receptor [18]. Influenza virus hemaglutinins bind the NKp46 of human NK cells [19]. Besides these NK receptor-interacting molecules, several kinds of bacteria/viruses are known to directly activate NK cells by PRR stimulation. Examples of microbial ligands for Toll-like receptors (TLRs) present in the NK cell membrane are as follows. Measles virus $\mathrm{H}$ protein interacts with TLR2 [20]. Mycobacteria muramyl dipeptides activate TLR2 residing on the NK cell membrane [21]. Plasmodium falciparum has an unidentified factor that interacts with TLR2/4 [22]. Some leishmania species have a lipophosphoglycan to bind to TLR2 [23]. Pam2 lipopeptides of a variety of bacteria serve as TLR2 ligands [24]. These factors also interact with mDC/Mf TLRs. Which TLRs in NK cells or accessory cells are more important for triggering NK cell activation in vivo should be an issue to be clarified.

\section{Overview of the mDC Pattern Sensing System}

$\mathrm{mDC}$, which comprise many subsets [including bone marrow-derived DC (BMDC) and CD $8 \alpha+$ DC], possess subset-specific pattern-recognition systems. TLR, NODlike receptors, and RIG-I-like receptors (RLR) are representative PRRs. The PRR repertoire in $\mathrm{mDC}$ has been described previously [17]. Two adaptors, i.e. MyD88 and TICAM-1 (TRIF), critically determine the signal pathways for TLRs, whereas interferon- $\beta$ promoter stimulator 1 (IPS-1) (Cardif, MAVS, VISA) is the only adaptor that governs MDA5/RIG-I signaling (fig. 1). These adaptors are engaged in type I IFN induction and NK activation via partly overlapped but distinct pathways in a cell type-specific manner. Here, we summarize the signal pathways for TLR and RLR relevant to NK activation.

Signaling Pathways That Operate through the MyD88 Adaptor

MyD88 is the most common adaptor in the TLR and interleukin (IL)-1R signaling pathways $[25,26]$. With the 


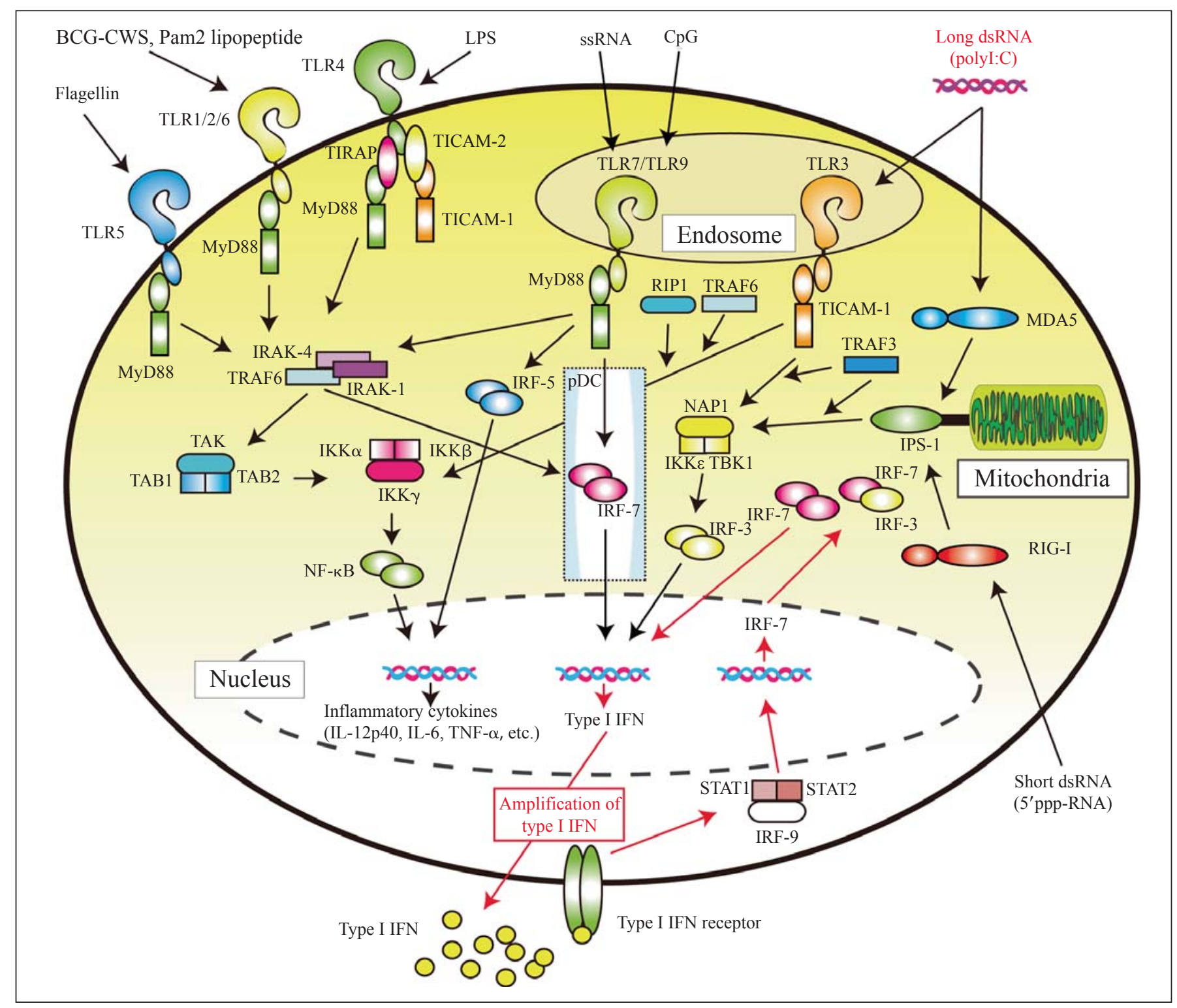

Fig. 1. TLR pattern-sensing system and cytoplasmic dsRNA recognition pathways. The TLR and RLR pattern-sensing systems involved in type I IFN induction and NK cell activation are depicted in a single cell model. pDC has a unique MyD88 pathway which is highlighted in the open square. All pathways except this MyD88 pathway function in BMDC of mouse and monocyte-derived DC of humans. Mouse spleen DC and human BDCA1/3positive DC have weak potential for recognition of cytoplasmic dsRNA, reflecting a relatively immature feature of DC. Once

exception of TLR3, all TLRs in mice and humans can couple with MyD88. Only the MyD88 in plasmacytoid $\mathrm{DC}$ (pDC) is linked to IFN-induced signaling [27]. In pDC, TLR7/9 recruit MyD88 and the IRAK4/IRAK1 complex, allowing the phosphorylation of IRAK1 [28].
TLR3 or TLR4 is stimulated, it transiently recruits TICAM-1 to form multimers. Subsequently, liberated TICAM-1 form a molecular complex named 'speckle' which serves as a nest for IRF-3/7 activation. In contrast, IPS-1 binds the outer membrane of mitochondria and forms an IRF-3/7-activating complex on the membrane. Once type I IFN is liberated, type I IFN production is amplified via the IFNAR pathway. NK cell activation occurs not only by soluble factors but also membrane proteins induced secondary to IRF-3 activation.

Activated IRAK1 forms a molecular complex with TRAF6/TRAF3/Osteopontin and IKK $\alpha$. After forming a complex with MyD88, activated IKK $\alpha$ activates nearby IFN regulatory factor (IRF)-7 which, in turn, is dimerized and translocated to the nucleus [29]. The IRF-7 di- 
mer then initiates transcription of the IFN- $\alpha$ gene. Once IFN- $\alpha$ is liberated, the IFNAR on the same cell or on other DC is activated to amplify the production of IFN- $\alpha[6$, $28,29]$. MyD88 also recruits IRF-5 which induces inflammatory cytokines, IL-6, IL-12p40, and tumor necrosis factor (TNF)- $\alpha$ but is minimally associated with type I IFN induction according to knockout (KO) mouse studies [30] (fig. 1).

MyD88-deficient mice show abolished responses to IL-1 $\beta$ and IL-18 and to the ligands for TLR2, TLR5, TLR7, and TLR9 [17, 25]. TLR4 signaling also requires MyD88 for inflammatory cytokine induction $[17,25]$. Thus, the MyD88 pathway is a common and pivotal pathway for IL$1 \mathrm{R}$ and TLR signaling. Type I IFN induction and NK cell activation are not impaired in MyD88-/- mice when the mice are stimulated with the TLR3 ligand polyI:C (a dsRNA analog) [9]. However, in vitro, NK activation via mDC TLR2 stimulation is abolished in MyD88-/- cells [24], as discussed later. The physiological importance of MyD88 in NK activation in vivo in a variety of TLR pathways remains to be proven.

\section{Signaling Pathways That Operate through the}

TICAM-1 (TRIF) Adaptor

TLR3 stimulation induces a unique output of IFN- $\beta$ induction [31]. TLR3 binds the adaptor TICAM-1 $[32,33]$. Overexpressed TICAM- 1 induces IFN- $\beta$, suggesting the importance of this adaptor in selecting the IFN- $\beta$-inducing pathway (fig. 1). Ultimately, this adaptor also acts in the TLR4 IFN- $\beta$-inducing pathway $[34,35]$. These results are consistent with those obtained from TRIF-/- mice [33].

IRF-3 activation induced by TLR4 signaling is independent of MyD88 and TIRAP/Mal, and instead depends on TICAM-1. To be more exact, another adaptor called TRAM (TICAM-2) serves as a bridging adaptor between TLR4 and TICAM-1 $[34,35]$. TICAM-2 is similar to TICAM-1 in terms of the amino acid sequence of its Toll/IL-1 receptor homology (TIR) domain (fig. 1). In TICAM-2deficient mice, both the MyD88-dependent pathway and the MyD88-independent pathway downstream of TLR4 signaling are defective, but TLR3 signaling remains intact [33]. TLR3 signaling also induces IRF-3 activation and IFN- $\beta$ production through direct coupling with TICAM-1 $[32,34]$. The IRF-3-activating pathway by TLR $3 / 4$ is greatly impaired in TICAM-1-deficient cells [36]. Thus, TICAM-1 is critically involved in TLR 3 and TLR4 signaling.

Two noncanonical Ік-B kinase homologs, i.e. Ік-B kinase-epsilon $(\mathrm{IKK} \varepsilon$ ) (also known as inducible IKK) [36, 37] and TRAF family member-associated NF- $\kappa$ B activa- tor (TANK)-binding kinase-I [TBK-I; also known as NF$\kappa \mathrm{B}$-activating kinase (NAK)], are involved in TICAM-1induced IRF-3 activation (fig. 1). These kinases physically couple with regulatory molecules, i.e. NAK-associated protein 1 (NAP1) or SINTBAD, and the complex can associate with TICAM-1 and induce phosphorylation and nuclear localization of IRF-3 [38, 39]. Furthermore, IRF3 -dependent gene expression induced by TLR 3 and TLR4 signaling has been found to be defective in TRAF3-/cells. Thus, TICAM-1 associates with TRAF3 for TLR3 and TLR4 signaling, causing the activation of IKK $\varepsilon / T B K-$ 1 and IRF-3 [40, 41].

\section{Signaling Pathways That Operate through the IPS-1}

(MAVS, Cardif) Adaptor

Since most RNA viruses replicate in the cytoplasm, membrane proteins including TLR cannot recognize virus-replicating dsRNA in the cytoplasm. RIG-I, a member of the RNA helicase family of PRRs, has been identified with ubiquitous distribution in the cytoplasm [42]. RIG-I contains 2 caspase-recruiting domain (CARD)like domains, i.e. DExD/H box RNA helicase and RHIM domains [42]. The helicase and RHIM domains interact with dsRNA or the $5^{\prime}$-triphosphate of virus-derived RNA with a short RNA duplex, whereas the CARD-like domains are required for interaction with IPS-1, an adaptor for activating downstream signaling pathways [17]. Furthermore, 2 additional RIG-I-like RNA helicases have been identified: MDA5 and LGP2 [43, 44]. MDA5 contains 2 CARD-like domains and a helicase domain, similar to RIG-I. MDA5 recognizes relatively long dsRNA in cytoplasm, whereas LGP2 lacks the CARD-like domains and is thought to positively regulate RIG-I and MDA5. These 2 signaling sensors recruit IPS-1, and IPS-1 induces the activation of IKK $\varepsilon /$ TBK-1 and IRF-3 [17] in a similar way to TICAM-1 (fig. 1).

IPS-1 contains a transmembrane domain that is rich in hydrophobic residues in its C-terminal tail and targets IPS- 1 to the mitochondria $[17,45]$. Notably, mitochondrial retention of IPS-1 is essential for IRF-3, IRF-7, and $\mathrm{NF}-\kappa \mathrm{B}$ activation, suggesting that signaling from mitochondria plays an important role in the antiviral immune response (fig. 1). The NS3/4A serine protease encoded by the hepatitis $\mathrm{C}$ virus has been demonstrated to target IPS1 for cleavage $[45,46]$. Using an in vitro cell culture infection system to introduce the hepatitis $\mathrm{C}$ virus, a putative cleavage site of IPS-1 was found to be located upstream of the transmembrane domain. The cleaved form of IPS-1, which lacks the transmembrane region, fails to activate IFN- $\beta$ and nuclear factor (NF)- $\kappa$ B. 
MDA5 detects long polyI:C or dsRNA, whereas RIG-I detects short dsRNA or the 5'-triphosphate end of RNA generated by viral polymerases $[47,48]$, indicating that these RNA helicases have different roles in the detection of viruses. Which of these pathways predominantly senses virus species is under examination. The simple interpretation that MDA5 is required for the recognition of picornaviruses and RIG-I recognizes that dsRNA-forming viruses [49] may be amended following the analysis of many virus species.

Mf, mDC, and fibroblast cells derived from RIG-I- or MDA5-deficient mice still displayed type I IFN induction in response to polyI:C stimulation, and the production of type I IFN was still observed in pDCs derived from IPS-1-/- mice [50, 51]. However, it is notable that the 2 pathways in the TLR system and the cytoplasmic IPS-1 pathway are required for dsRNA responses in different situations and cell types [50, 52]. Collectively, these observations indicate that the various modes of the RNA pattern-sensing system cooperate to detect cytoplasmic virus replication in a variety of tissues/organs.

\section{NK Cell Activation via the TLR2/MyD88 Pathway in Mf and $\mathrm{mDC}$}

In vitro stimulation of mouse $\mathrm{mDC}$ or $\mathrm{Mf}$ with TLR2 stimulators BCG-CWS (cell wall skeleton) or Pam2 lipopeptide causes these cells to become NK activation inducers $[24,53]$. Both TLR2 and MyD88 are indispensable for this type of NK cell activation. At least in in vitro studies, MyD88-/- Mf fail to reciprocally activate NK cells via cell-cell contact [54]. Mf MyD88 signaling through TLRs is reported to induce expression of the NKG2D ligand retinoic acid early induced transcript (RAE)-1 [55]. NK cells are then activated by MyD88-stimulated Mf. The NKG2D receptor on NK cells is downregulated by the RAE-1-NKG2D interaction [55]. MyD88 can be activated via the inflammasome pathway in human Mf [56] without the participation of TLR2. IL-1 $\beta$ or IL-18 (or possibly IL-33) liberated from Plasmodium-infected Mf may convert these cells into NK-activating Mf through IL-1 $\beta / \mathrm{IL}-$ 18 receptors [57, 58]. MyD88 in NK cells also participates in this type of NK activation $[53,59]$.

However, this is not the case in mDC. Although IL$12 \mathrm{p} 70$ is produced in $\mathrm{mDC}$ in response to the TLR2 ligand BCG-CWS, the role of IL-12 in NK activation is peripheral in the mouse system. There are at least 2 modes of MyD88-dependent NK cell activation in mDC: (1) MyD88 in pDC can couple with TLR7 or TLR9 to activate the
IFN- $\alpha$-inducing pathway, and this pathway also participates in NK cell activation, presumably through type I IFN liberated by pDC $[60,61]$; (2) in contrast, MyD88-/$\mathrm{mDC}$ lose the ability to mature in response to TLR2 ligands. For example, the TLR2 ligand Pam2CSK4 facilitates $\mathrm{mDC}$-mediated $\mathrm{NK}$ cell activation in the case of wild-type $\mathrm{mDC}$ [24]. If wild-type $\mathrm{mDC}$ are replaced with MyD88-/- mDC, cell contact-mediated NK activation is hampered even when the cells are stimulated with Pam2 lipopeptide. Although TLR2-/- mDC largely abrogate the NK cell-activating function, slight functional activity remains in TLR2-/- mDC compared with MyD88-/- mDC, suggesting the presence of TLR2-independent MyD88activating pathways, which may reflect the action of NOD-like receptor inflammatory pathways. Hence, NK cell activation proceeds through TLR2-dependent and TLR2-independent pathways of $\mathrm{mDC}$, both of which involve MyD88. Furthermore, TLR2/MyD88 in NK cells minimally participates in direct NK activation $[24,53]$.

\section{NK Cell Activation via the TICAM-1 or IPS-1 Pathways in $\mathrm{mDC}$}

It has long been established that a dsRNA analog, i.e. polyI:C, serves as an inducer of NK activation [62, 63]. In vivo administration of polyI:C to mice and in vitro exogenous addition of polyI:C to a mixture of BMDC and NK cells both resulted in activation of NK cells. Ex vivo studies using cells from $\mathrm{KO}$ mice have helped reveal how polyI:C activates NK cells. PolyI:C, unlike viral or in vitro-transcribed dsRNA, is internalized into the endosome and cytoplasm where it is recognized by TLR 3 and MDA5, respectively $[9,11]$ (fig. 2). IPS-1 is the adaptor for MDA5/ RIG-I, while TICAM- 1 is the adaptor for TLR3 $[32,43,64]$ (fig. 1). Using the gene-disrupted mouse cells of MDA5-/and TLR3-/- or IPS-1-/- and TICAM-1-/- mDC, the pathway more involved in NK cell activation was examined in vitro [9-11]. In BMDC, the MDA5/IPS-1 pathway is more important than the TLR3/TICAM-1 pathway, as determined by the expression of NK activation marker CD69 and NK cytotoxicity [11], whereas the reverse is true in IFN- $\gamma$ production by NK cells [64]. NK activation induced in mice injected with polyI:C is completely abrogated in double KO (IPS-1-/- and TICAM-1-/-) mice, suggesting that these 2 pathways are both required for polyI:C-mediated NK activation $[10,11]$.

Cell contact-mediated NK activation was found to dominantly occur in IRF-3 activation [64] and $\mathrm{mDC}$ by depletion studies [65]. Cytokines, including IL-12p40, IL- 


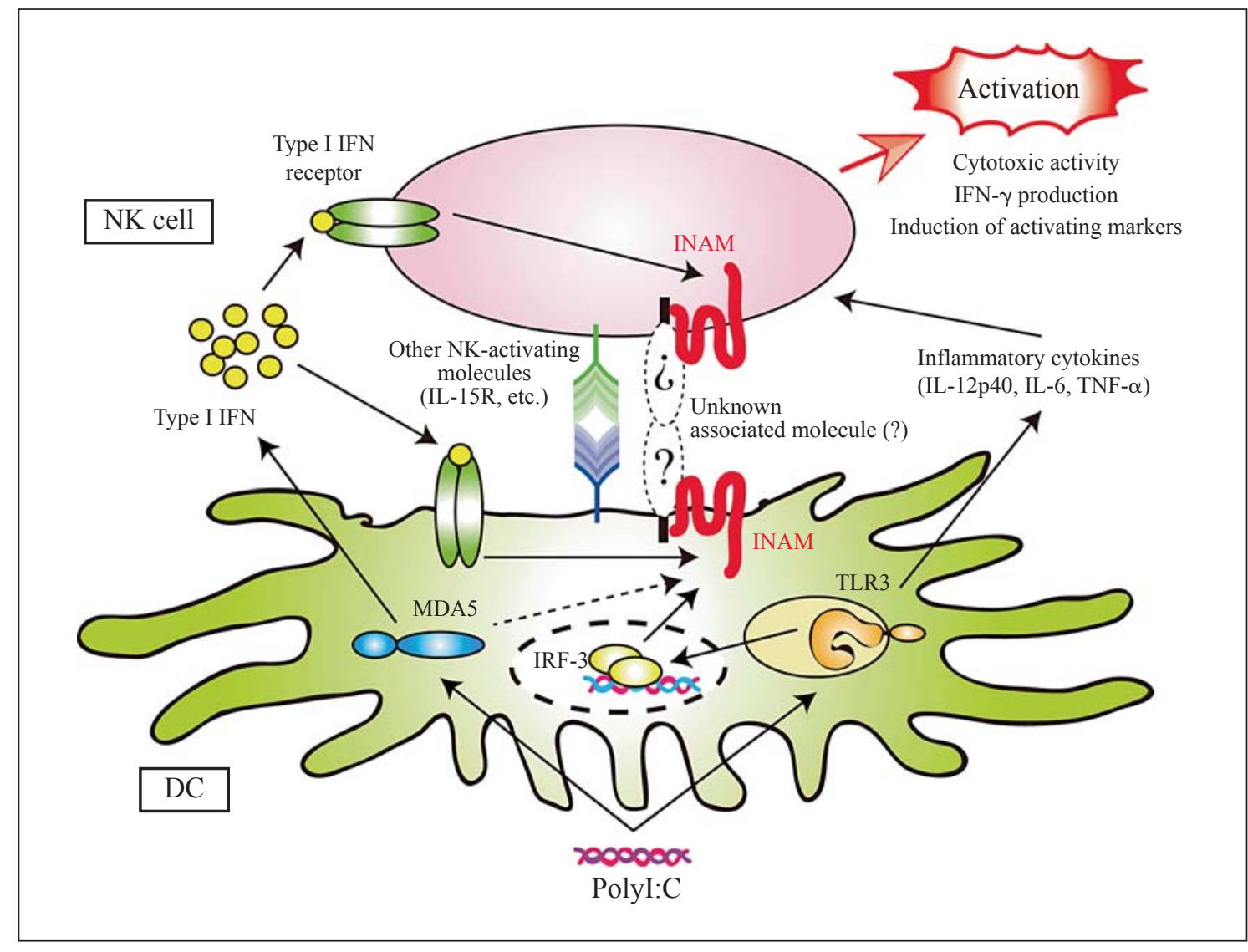

Fig. 2. Induction of INAM-mediated NK cell activation. PolyI:C-stimulated BMDC induce NK cell activation in vitro. INAM is responsible for BMDC contact-mediated NK activation. IRF-3 activation by polyI:C is crucial for INAM upregulation in BMDC, which results in the BMDC-mediated activation of NK cells. Upregulation of INAM on NK cells also facilitates NK cell activation in $\mathrm{mDC}-\mathrm{NK}$ coculture.

15 , and type I IFN, are produced in $\mathrm{mDC}$ in response to polyI:C stimulation. Both cell contact and cytokine production mediate NK activation in vitro but cytokines are known to be dispensable for NK activation by polyI:Cstimulated $\mathrm{mDC}$ in mice [64]. In vivo injected polyI:C allowed mice to mature splenic DCs $[10,11]$. In vivo, bone marrow transplantation chimera analysis suggested that the TLR3-TICAM-1 pathway is important in myeloid cells, along with the IPS-1 pathway in nonmyeloid cells, in driving cytolytic activity by polyI:C [11] (fig. 3). Thus, nonmyeloid-derived soluble factors (mainly IFN- $\alpha / \beta$ ) operate in NK activation in this case. In addition, splenic $\mathrm{CD} 8 \alpha+\mathrm{DC}$ rather than CD $8 \alpha-\mathrm{DC}$ is crucial for driving NK activation via cell-cell contact [10].

The molecule responsible for $\mathrm{mDC}-\mathrm{NK}$ contact activation has recently been investigated [64]. There are several polyI:C-inducible membrane-associated molecules in $\mathrm{mDC}$ and one of these molecules, designated INAM (IRF-3-dependent NK cell activating molecule), participates in $\mathrm{mDC}-\mathrm{NK}$ reciprocal activation (fig. 2). However, when overexpressed in non-NK target cells, INAM does not act as an NK-activating ligand; it works only on $\mathrm{mDC} /$ $\mathrm{Mf}$ for NK activation. Since INAM is predicted to have a tetraspanin-like sequence, unidentified molecules coupling to INAM may foster mDC-NK contact.

\section{NK Cell Activation in Humans and Mice}

In human monocyte-derived DC [66] and mouse CD8 $\alpha+$-like human DC (BDCA3+/XCR1+) [67, 68], the early response to dsRNA (including polyI:C and polyA:U) induces the production of IL-12p40 and type I IFN via the TLR3/TICAM-1 pathway. These early-phase cytokines 


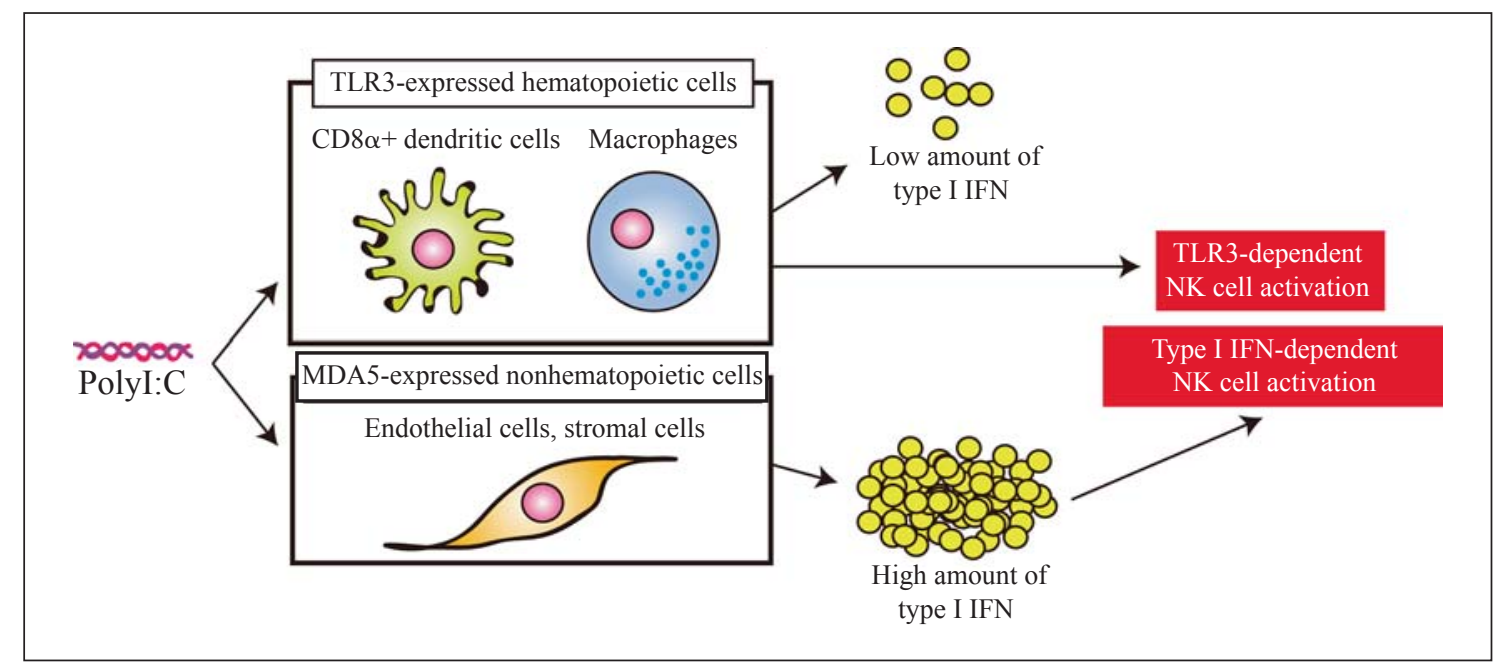

Fig. 3. The IPS-1 pathway in nonmyeloid cells and TLR3 in myeloid cells participate in the activation of NK cells. Mice i.v. injected with polyI:C activate NK cells. Two distinct pathways are involved in NK cell activation in this case: (1) TLR3 in Mf and mDC recognize the i.v. injected polyI:C and drive the internal NK activation pathway, and (2) nonhematopoietic cells recognize the polyI:C by their MDA5 in the cytoplasm to produce a large amount of type I IFN, which in turn activates Mf/DC for NK activation.

play a key role in priming NK cells to induce a low amount of IFN- $\gamma$ in vitro. In vitro administered dsRNA also activates NK cells via direct stimulation of the RIG-I pathway in NK cells. In the following phase, $\mathrm{mDC}$ are recruited to draining lymph nodes to encounter NK cells. Subsequently, mDC-NK contact occurs inducing full maturation of NK cells. At this stage, NK cells engage in significant IFN- $\gamma$ production. This recent observation is in close agreement with the results reported in human in vitro cocultured liver DC and NK cells [69]. These findings clearly reveal the importance of mDC IL-12p70 and the NK cell RIG-I pathway in NK cell priming in humans.

In mouse in vitro studies, mouse BMDC or CD8 $\alpha+$ splenic DC activate NK cells via cell-cell contact rather than IL-12p70 or type I IFN. BMDC, as well as CD8 $\alpha+$ splenic DC, express TLR3 mRNA, and polyI:C stimulation induces activation of both the TICAM-1 pathway and the IPS-1 pathway [9-11, 64]. IL-12p40 (which is likely the p40 dimer that inhibits IL-12R-derived signaling), instead of IL-12p70, is produced in response to polyI:C in mouse DC-NK coculture studies [64]. A membrane molecule, i.e. INAM, expressed secondary to IRF-3 activation in BMDC or CD8 $\alpha+$ DC stimulates initial DC-mediated NK activation. Full activation of NK cells, including cytolytic activity against target molecules, is provoked only secondarily to DC-NK contact in mice.
In contrast, in vivo studies on $\mathrm{NK}$ cell activation have been performed in mice via intravenous (i.v.) injection of polyI:C. NK activation occurs in response to i.v. injected polyI:C, and NK activation has been shown to depend on the MDA5/IPS-1 pathway and TLR3/TICAM-1pathway in KO mice [11] (fig. 3). Surprisingly, in bone marrow chimera studies, initial induction of type I IFN by MDA5 from nonmyeloid cells played a crucial role in splenic DC maturation. $\mathrm{CD} 8 \alpha+$ DC maturation secondarily triggered NK cell activation. If this is the case, myeloid cell TLR3 and nonmyeloid cell MDA5 actually participate in polyI:C-dependent maturation of splenic DC to drive NK activation, at least at an early phase of i.v. administration in vivo. Presumably, stromal or vascular endothelial cells are a source of MDA5-mediated type I IFN induction, which in turn activates splenic DC. There are several subsets of DC in the mouse spleen. Only CD $8 \alpha+$ DC express high TLR3 and participate in NK activation [10, 70]. On the other hand, intraperitoneal administration of polyI:C first activates $\mathrm{Mf}$ in the peritoneal cavity of mice [71]. The route of polyI:C administration may therefore stimulate different RNA sensors to activate IRF-3. IL-12p70 has a minimal role in mouse DC-mediated NK activation.

It is currently unclear which mode of NK activation, TICAM-1 or IPS-1, is dominant in other mammals and vertebrates. NK cells and the TICAM-1 and IPS-1 pathways are conserved across vertebrates. Differential re- 
sponses to polyI:C in cytokine production and NK activation in other animals may be partly due to the systemic differences in RNA recognition in different cell types and tissues.

\section{Perspectives}

NK cell activation is an important event in the immune response to cancer or infectious diseases. Recent molecular/cellular analyses suggest that the cells and molecular mechanisms involved in NK cell activation differ between in vivo PAMP-stimulated mice and in vitro PAMP-stimulated cell cocultures. A discrepancy also appears in in vitro NK activation studies in humans and mice. The basal IFN-inducing properties have been reported in mice but not in humans [6]. The response to PAMP also differs depending on the delivery routes. Caution is therefore necessary when adapting the results from $\mathrm{KO}$ mice to human clinical studies. Only $5 \mu \mathrm{g}$ of polyI:C sufficiently induces IFN- $\beta$ from human fibro- blasts which express TLR3 on the cell surface, but $>150$ $\mu \mathrm{g}$ is still insufficient for mouse fibroblasts [72, 73]. Although polyI:C is effective for NK activation, it often induces a life-threatening cytokine storm in mice [74]. A future aim is to activate NK cells with no side effects in human patients. If this can be achieved, NK cell activation could be applied to the establishment of effective vaccines and immunotherapies.

\section{Acknowledgements}

We are grateful to Drs. H. Oshiumi, H. Takaki, A. Watanabe, H.H. Aly, S. Yamazaki, and T. Ebihara for invaluable discussions. This work was supported in part by Grants in Aid from the Ministry of Education, Science, and Culture and the Ministry of Health, Labor, and Welfare of Japan, and by the NorthTec Foundation, the Yakult Foundation, the Waxman Foundation, and the Akiyama Life Science Foundation. Financial support from the Sapporo Biocluster 'Bio-S' the Knowledge Cluster Initiative of the MEXT, and the Program of Founding Research Centers for Emerging and Reemerging Infectious Diseases, MEXT, is gratefully acknowledged.

\section{References}

1 Trinchieri G: Biology of natural killer cells. Adv Immunol 1989;47:187-376.

- 2 Bryceson YT, March ME, Ljunggren HG, Long EO: Activation, coactivation, and costimulation of resting human natural killer cells. Immunol Rev 2006;214:73-91.

-3 Moretta A: Natural killer cells and dendritic cells: rendezvous in abused tissue. Nat Rev Immunol 2002;2:957-964.

-4 Granucci F, Zanoni I, Ricciardi-Castagnoli P: Central role of dendritic cells in the regulation and deregulation of immune responses. Cell Mol Life Sci 2008;65:1683-1697.

5 Joffre O, Nolte MA, Spörri R, Reis e Sousa C: Inflammatory signals in dendritic cell activation and the induction of adaptive immunity. Immunol Rev 2009;227:234-247.

6 Takaoka A, Taniguchi T: New aspects of IFN- $\alpha / \beta$ signalling in immunity, oncogenesis and bone metabolism. Cancer Sci 2003; 94:405-411.

7 Kono H, Rock KL: How dying cells alert the immune system to danger. Nat Rev Immunol 2008;8:279-289.

${ }_{8}$ Seya T, Shime H, Ebihara T, Oshiumi H, Matsumoto M: Pattern recognition receptors of innate immunity and their application to tumor immunotherapy. Cancer Sci 2010;101:313-320.
-9 Akazawa T, Ebihara T, Okuno M, Okuda Y, Shingai M, Tsujimura K, Takahashi T, Ikawa M, Okabe M, Inoue N, Okamoto-Tanaka M, Ishizaki H, Miyoshi J, Matsumoto M, Seya T: Antitumor NK activation induced by the Toll-like receptor 3-TICAM-1 (TRIF) pathway in myeloid dendritic cells. Proc Natl Acad Sci USA 2007;104:252-257.

- 10 Miyake T, Kumagai Y, Kato H, Guo Z, Matsushita K, Satoh T, Kawagoe T, Kumar H, Jang MH, Kawai T, Tani T, Takeuchi O, Akira S: Poly I:C-induced activation of NK cells by CD8 alpha+ dendritic cells via the IPS-1 and TRIF-dependent pathways. J Immunol 2009;183:2522-2528.

11 McCartney S, Vermi W, Gilfillan S, Cella M, Murphy TL, Schreiber RD, Murphy KM, Colonna M: Distinct and complementary functions of MDA5 and TLR3 in poly(I:C)mediated activation of mouse NK cells. J Exp Med 2009;206:2967-2976.

12 Lanier LL: Up on the tightrope: natural killer cell activation and inhibition. Nat Immunol 2008;9:495-502.

13 Dimasi N, Moretta L, Biassoni R: Structure of the Ly49 family of natural killer (NK) cell receptors and their interaction with $\mathrm{MHC}$ class I molecules. Immunol Res 2004;30:95104.

14 Sun JC, Beilke JN, Lanier LL: Adaptive immune features of natural killer cells. Nature 2009;457:557-561.
15 Cooper MA, Colonna M, Yokoyama WM: Hidden talents of natural killers: NK cells in innate and adaptive immunity. EMBO Rep 2009;10:1103-1110.

16 Newman KC, Riley EM: Whatever turns you on: accessory-cell-dependent activation of NK cells by pathogens. Nat Rev Immunol 2007;7:279-291.

17 Kawai T, Akira S: The roles of TLRs, RLRs and NLRs in pathogen recognition. Int Immunol 2009;21:317-337.

18 Arase H, Mocarski ES, Campbell AE, Hill $\mathrm{AB}$, Lanier LL: Direct recognition of cytomegalovirus by activating and inhibitory NK cell receptors. Science 2002;296:13231326.

19 Mandelboim O, Lieberman N, Lev M, Paul L, Arnon TI, Bushkin Y, Strominger JL, Yewdell JW, Porgador A: Recognition of haemagglutinins on virus-infected cells by NKp46 activates lysis by human natural killer cells. Nature 2001;409:1055-1060.

20 Bieback K, Lien E, Klagge IM, Avota E, Schneider-Schaulies J, Duprex WP, Wagner $\mathrm{H}$, Kirschning CJ, ter Meulen V, SchneiderSchaulies S: Hemagglutinin protein of wildType measles virus activates Toll-like receptor 2 signaling. J Virol 2002;76:8729-8736. 
-21 Uehori J, Fukase K, Akazawa T, Uematsu T, Akira S, Funami S, Shingai M, Matsumoto M, Azuma I, Toyoshima K, Kusumoto S, Seya T: Dendritic cell maturation induced by muramyl dipeptide (MDP) derivatives: monoacylated MDP confers TLR2/TLR4 activation. J Immunol 2005; 174:7096-7103.

-22 Korbel DS, Newman KC, Almeida CR, Davis DM, Riley EM: Heterogenous human NK cell responses to Plasmodium falciparum-infected erythrocytes. J Immunol 2005; 175 : 7466-7473.

23 Becker I, Salaiza N, Aguirre M, Delgado J, Carrillo-Carrasco N, Kobeh LG, Ruiz A, Cervantes R, Torres AP, Cabrera N, González A, Maldonado C, Isibasi A: Leishmania lipophosphoglycan (LPG) activates NK cells through Toll-like receptor-2. Mol Biochem Parasitol 2003;130:65-74.

- 24 Azuma M, Sawahata R, Akao Y, Ebihara T, Yamazaki S, Matsumoto M, Hashimoto M, Fukase K, Fujimoto Y, Seya T: The peptide sequence of diacyl lipopeptides determines dendritic cell TLR2-mediated NK activation. PLoS One 2010;5:e12550.

-25 Adachi O, Kawai T, Takeda K, Matsumoto M, Tsutsui H, Sakagami M, Nakanishi K, Akira S: Targeted disruption of the MyD88 gene results in loss of IL-1- and IL-18-mediated function. Immunity 1998;9:143150.

-26 Kawai T, Adachi O, Ogawa T, Takeda K, Akira S: Unresponsiveness of MyD88-deficient mice to endotoxin. Immunity 1999;11:115122.

27 Honda K, Ohba Y, Yanai H, Negishi H, Mizutani T, Takaoka A, Taya C, Taniguchi T: Spatiotemporal regulation of MyD88-IRF-7 signaling for robust type I interferon induction. Nature 2005;434:1035-1040.

$\checkmark 28$ Uematsu S, Akira S: Toll-like receptors and type I interferons. J Biol Chem 2007;282: 15319-1532.

-29 Honda K, Taniguchi T: IRFs: master regulators of signalling by Toll-like receptors and cytosolic pattern-recognition receptors. Nat Rev Immunol 2006;6:644-658.

- 30 Takaoka A, Yanai H, Kondo S, Duncan G, Negishi H, Mizutani T, Kano S, Honda K, Ohba Y, Mak TW, Taniguchi T: Integral role of IRF-5 in the gene induction programme activated by Toll-like receptors. Nature 2005; 434:243-249.

- 31 Matsumoto M, Funami K, Tanabe M, Oshiumi H, Shingai M, Seto Y, Yamamoto A, Seya T: Subcellular localization of Toll-like receptor 3 in human dendritic cells. J Immunol 2003;171:3154-3162.

- 32 Oshiumi H, Matsumoto M, Funami K, Akazawa T, Seya T: TICAM-1, an adaptor molecule that participates in Toll-like receptor 3 -mediated interferon-beta induction. Nat Immunol 2003;4:161-167.
3 Yamamoto M, Sato S, Hemmi H, Hoshino K, Kaisho T, Sanjo H, Takeuchi O, Sugiyama M, Okabe M, Takeda K, Akira S: Role of adaptor TRIF in the MyD88-independent toll-like receptor signaling pathway. Science 2003; 301:640-643.

34 Oshiumi H, Sasai M, Shida K, Fujita T, Matsumoto M, Seya T: TIR-containing adapter molecule (TICAM)-2, a bridging adapter recruiting to toll-like receptor 4 TICAM-1 that induces interferon-beta. J Biol Chem 2003; 278:49751-49762.

35 Fitzgerald KA, Rowe DC, Barnes BJ, Caffrey DR, Visintin A, Latz E, Monks B, Pitha PM, Golenbock DT: LPS-TLR4 signaling to IRF3/7 and NF-kappaB involves the Toll adapters TRAM and TRIF. J Exp Med 2003;198: 1043-1055.

36 Fitzgerald KA, McWhirter SM, Faia KL, Rowe DC, Latz E, Golenbock DT, Coyle AJ, Liao SM, Maniatis T: IKK-epsilon and TBK1 are essential components of the IRF3 signaling pathway. Nat Immunol 2003;4:491-496.

- 37 Sharma S, tenOever BR, Grandvaux N, Zhou GP, Lin R, Hiscott J: Triggering the interferon antiviral response through an IKK-related pathway. Science 2003;300:1148-1151.

38 Sasai M, Oshiumi H, Matsumoto M, Inoue N, Fujita F, Nakanishi M, Seya T: Cutting edge: NF-kappaB-activating kinase-associated protein 1 participates in TLR3/Toll-IL-1 homology domain-containing adapter molecule-1-mediated IFN regulatory factor 3 activation. J Immunol 2005;174:27-30.

-39 Ryzhakov G, Randow F: SINTBAD, a novel component of innate antiviral immunity, shares a TBK1-binding domain with NAP1 and TANK. EMBO J 2007;26:3180-3190.

40 Häcker H, Redecke V, Blagoev B, Kratchmarova I, Hsu LC, Wang GG, Kamps MP, Raz E, Wagner H, Häcker G, Mann M, Karin M: Specificity in Toll-like receptor signalling through distinct effector functions of TRAF3 and TRAF6. Nature 2006;439:204207.

41 Oganesyan G, Saha SK, Guo B, He JQ, Shahangian A, Zarnegar B, Perry A, Cheng G: Critical role of TRAF3 in the Toll-like receptor-dependent and -independent antiviral response. Nature 2006;439:208-211.

42 Yoneyama M, Kikuchi M, Natsukawa T, Shinobu N, Imaizumi T, Miyagishi M, Taira K, Akira S, Fujita T: The RNA helicase RIG-I has an essential function in double-stranded RNA-induced innate antiviral responses. Nat Immunol 2004;5:730-737.

43 Yoneyama M, Kikuchi M, Matsumoto K, Imaizumi T, Miyagishi M, Taira K, Foy E, Loo YM, Gale M Jr, Akira S, Yonehara S, Kato A, Fujita T: Shared and unique functions of the DExD/H-box helicases RIG-I, MDA5, and LGP2 in antiviral innate immunity. J Immunol 2005;175:2851-2858.
44 Saito T, Hirai R, Loo YM, Owen D, Johnson CL, Sinha SC, Akira S, Fujita T, Gale M Jr: Regulation of innate antiviral defenses through a shared repressor domain in RIG-I and LGP2. Proc Natl Acad Sci USA 2007;104: 582-587.

45 Li XD, Sun L, Seth RB, Pineda G, Chen ZJ: Hepatitis C virus protease NS3/4A cleaves mitochondrial antiviral signaling protein off the mitochondria to evade innate immunity. Proc Natl Acad Sci USA 2005; 102:1771717722.

46 Loo YM, Owen DM, Li K, Erickson AK, Johnson CL, Fish PM, Carney DS, Wang T, Ishida $\mathrm{H}$, Yoneyama M, Fujita T, Saito T, Lee WM, Hagedorn CH, Lau DT, Weinman SA, Lemon SM, Gale MJ: Viral and therapeutic control of IFN-beta promoter stimulator 1 during hepatitis $\mathrm{C}$ virus infection. Proc Natl Acad Sci USA 2006;103:6001-6006.

47 Hornung V, Ellegast J, Kim S, Brzozka K, Jung A, Kato H, Poeck H, Akira S, Conzelmann KK, Schlee M, Endres S, Hartmann G: $5^{\prime}$-Triphosphate RNA is the ligand for RIG-I. Science 2006;314:994-997.

48 Pichlmair A, Schulz O, Tan CP, Naslund TI, Liljestrom P, Weber F, Reis e Sousa C: RIGI-mediated antiviral responses to singlestranded RNA bearing 5'-phosphates. Science 2006;314:997-1001

49 Kato H, Takeuchi O, Sato S, Yoneyama M, Yamamoto M, Matsui K, Uematsu S, Jung A, Kawai T, Ishii KJ, Yamaguchi O, Otsu K, Tsujimura T, Koh CS, Reis e Sousa C, Matsuura Y, Fujita T, Akira S: Differential roles of MDA5 and RIG-I helicases in the recognition of RNA viruses. Nature 2006;441:101105.

50 Kato H, Sato S, Yoneyama M, Yamamoto M, Uematsu S, Matsui K, Tsujimura T, Takeda K, Fujita T, Takeuchi O, Akira S: Cell typespecific involvement of RIG-I in antiviral response. Immunity 2005;23:19-28.

51 Kochs G, Bauer S, Vogt C, Frenz T, Tschopp J, Kalinke U, Waibler Z: Thogoto virus infection induces sustained type I interferon responses that depend on RIG-I-like helicase signaling of conventional dendritic cells. J Virol 2010;84:12344-12350.

52 Matsumoto M, Oshiumi H, Seya T: Antiviral responses induced by the TLR3 pathway. Rev Med Virol 2011, Epub ahead of print.

53 Martinez J, Huang X, Yang Y: Direct TLR2 signaling is critical for NK cell activation and function in response to vaccinia viral infection. PLoS Pathog 2010;6:e1000811.

54 Sawaki J, Tsutsui H, Hayashi N, Yasuda K, Akira S, Tanizawa T, Nakanishi K: Type 1 cytokine/chemokine production by mouse NK cells following activation of their TLR/ MyD88-mediated pathways. Int Immunol 2007;19:311-320.

55 Hamerman JA, Ogasawara K, Lanier LL: Cutting edge: Toll-like receptor signaling in macrophages induces ligands for the NKG2D receptor. J Immunol 2004;17:2001-2005. 
56 Cole LE, Santiago A, Barry E, Kang TJ, Shirey KA, Roberts ZJ, Elkins KL, Cross AS, Vogel SN: Macrophage proinflammatory response to Francisella tularensis live vaccine strain requires coordination of multiple signaling pathways. J Immunol 2008;180:68856891.

-57 Adachi K, Tsutsui H, Kashiwamura S, Seki E, Nakano H, Takeuchi O, Takeda K, Okumura K, Van Kaer L, Okamura H, Akira S, Nakanishi K: Plasmodium berghei infection in mice induces liver injury by an IL-12- and Toll-like receptor/myeloid differentiation factor 88-dependent mechanism. J Immunol 2001;167:5928-5934.

58 Baratin M, Roetynck S, Lépolard C, Falk C, Sawadogo S, Uematsu S, Akira S, Ryffel B, Tiraby JG, Alexopoulou L, Kirschning CJ, Gysin J, Vivier E, Ugolini S: Natural killer cell and macrophage cooperation in MyD88dependent innate responses to Plasmodium falciparum. Proc Natl Acad Sci USA 2005; 102:14747-14752.

-59 Akao Y, Ebihara T, Masuda H, Saeki Y, Akazawa T, Hazeki K, Hazeki O, Matsumoto M, Seya T: Enhancement of antitumor natural killer cell activation by orally administered Spirulina extract in mice. Cancer Sci 2009; 100:1494-501.

-60 Krug A, French AR, Barchet W, Fischer JA, Dzionek A, Pingel JT, Orihuela MM, Akira S, Yokoyama WM, Colonna M: TLR9-dependent recognition of MCMV by IPC and DC generates coordinated cy tokine responses that activate antiviral NK cell function. Immunity 2004;21:107-119.
61 Hoshino K, Sugiyama T, Matsumoto M, Tanaka T, Saito M, Hemmi H, Ohara O, Akira S, Kaisho T: IkappaB kinase-alpha is critical for interferon-alpha production induced by Toll-like receptors 7 and 9. Nature 2006; 440:949-953.

-62 Djeu JY, Heinbaugh JA, Holden HT, Herberman RB: Augmentation of mouse natural killer cell activity by interferon and in terferon inducers. J Immunol 1979;122: 175-181.

63 Wiltrout RH, Salup RR, Twilley TA, Talmadge JE: Immunomodulation of natural killer activity by polyribonucleotides. J Biol Response Mod 1985;4:512-517.

64 Ebihara T, Azuma M, Oshiumi H, Kasamatsu J, Iwabuchi K, Matsumoto K, Saito T, Taniguchi T, Matsumoto M, Seya T: Identification of a polyI:C-inducible membrane protein that participates in dendritic cell-mediated natural killer cell activation. J Exp Med 2010;207:2675-2687.

65 Lucas M, Schachterle W, Oberle K, Aichele P, Diefenbach A: Dendritic cells prime natural killer cells by trans-presenting interleukin 15. Immunity 2007;26:503-517.

66 Matsumoto M, Funami K, Tanabe M, Oshiumi H, Shingai M, Seto Y, Yamamoto A, Seya T: Subcellular localization of Toll-like receptor 3 in human dendritic cells. J Immunol 2003;171:3154-3162.

67 Crozat K, Guiton R, Contreras V, Feuillet V, Dutertre CA, Ventre E, Vu Manh TP, Baranek T, Storset AK, Marvel J, Boudinot $\mathrm{P}$, Hosmalin A, Schwartz-Cornil I, Dalod M: The XC chemokine receptor 1 is a conserved selective marker of mammalian cells homologous to mouse CD8alpha+ dendritic cells. J Exp Med 2010;207:1283-1292.
68 Bachem A, Güttler S, Hartung E, Ebstein F, Schaefer M, Tannert A, Salama A, Movassaghi K, Opitz C, Mages HW, Henn V, Kloetzel PM, Gurka S, Kroczek RA: Superior antigen cross-presentation and XCR1 expression define human CD11c+CD141+ cells as homologues of mouse CD8+ dendritic cells. J Exp Med 2010;207:1273-1281.

69 Tu Z, Bozorgzadeh A, Pierce RH, Kurtis J, Crispe IN, Orloff MS: TLR-dependent cross talk between human Kupffer cells and NK cells. J Exp Med 2008;205:233-244.

70 Jelinek I, Leonard JN, Price GE, Brown KN, Meyer-Manlapat A, Goldsmith PK, Wang Y, Venzon D, Epstein SL, Segal DM: TLR3-specific double-stranded RNA oligonucleotide adjuvants induce dendritic cell cross-presentation, CTL responses, and antiviral protection. J Immunol 2011;186:2422-2429.

71 Wu CY, Monie A, Yang HY, Wu Tc, Hung CF: Intraperitoneal administration of polyI:C with polyethylenimine leads to significant antitumor immunity against murine ovarian tumors. Cancer Immunol Immunother 2011, in press.

72 Matsumoto M, Kikkawa S, Kohase M, Miyake K, Seya T: Establishment of a monoclonal antibody against human Toll-like receptor 3 that blocks double-stranded RNAmediated signaling. Biochem Biophys Res Commun 2002;293:1364-1369.

73 Matsumoto M, Seya T: TLR3: interferon induction by double-stranded RNA including poly(I:C). Adv Drug Deliv Rev 2008;60:805812 .

74 Absher M, Stinebring WR: Toxic properties of a synthetic double-stranded RNA: endotoxin-like properties of poly I - poly C, an interferon stimulator. Nature 1969;223:715-717. 